\title{
ASSESSMENT OF FREIGHT VEHICULAR MOVEMENT ON ARTERIAL ROADS OF DELHI FOR SAFETY OF ROAD USERS
}

\author{
Farhat Azad ${ }^{1}$, Pritikana Das ${ }^{2}$, Sewa Ram ${ }^{3}$ \\ 1,2 Department of Transportation Planning and Environmental Division, CSIR-CRRI, New Delhi, India \\ ${ }^{3}$ Department of Transportation Planning, School of Planning and Architecture, New Delhi, India
}

Received 18 January 2019; accepted 5 May 2019

\begin{abstract}
In the direction of fulfilling the needs of thickly populated NCT, highways are being used constantly by freight vehicles, in a very chaotic manner. It has been noticed that more than a lakh trucks enter Delhi daily to pass from one region to another. It creates congestion for common people residing in and around Delhi. Number of accidents in Delhi is more than thrice compared to Mumbai and at least two times more in comparison to Bengaluru's road fatalities. Mostly, trucks entering Delhi are overloaded resulting in higher levels of emissions and threat to road safety. Due to lack in managing these freight vehicular movements the lives of people residing in NCT has affected socially, economically and health wise. The country loses Rs 60,000 crore a year due to congestion including fuel wastage. Detailed study on present initiatives taken by both Central and Delhi government, assessment of freight in Delhi-NCR has been analyzed so that proactive decisions by the concerned ministries and organizations can be taken by modifying the policies which will contribute for better lives of people. SWOT analysis, crash prediction modelling and estimation of accident severity index have been used for analysis and safety measures have been suggested.
\end{abstract}

Keywords: SWOT analysis, crash prediction, SMEED model, crash severity index.

\section{Introduction}

In India road freight constitutes around $63 \%$ of the total freight movement (IFTMAF, 2015). Indian freight transport market is expected to grow at a CAGR of $13.35 \%$ by 2020 driven by the growth in the manufacturing, retail, FMCG and e-commerce sectors (NTDPC, 2014). Indian freight volume has increased at a rate of compounded and annual growth rate of $9.08 \%$ and vehicles are growing at a rate of $10.76 \%$, whereas the road length is just increasing at a rate of $4.01 \%$. This has resulted paucity of road space to accommodate vehicles and to increase the speed for less fuel consumption and wastage (TCI-IIMC, 2017). NCT has got highest road network density i.e $2103 \mathrm{~km} / 100$ sqkm in India (TDFS-DIMTS, 2010). To fulfil the needs of thickly populated NCT, these highways are being used constantly by freight vehicles, in a very chaotic manner. It has been noticed that more than a lakh trucks enter Delhi daily to pass from one region to the other. These trucks create lot of congestion and traffic jams for common people residing in and around Delhi. Because of increased freight vehicular movement and its mismanagement situation in Delhi-NCR, the NCR Planning Board took notice of this chaotic situation and prepared a Functional

${ }^{2}$ Corresponding author: pritikana.crri@nic.in 
Plan on Transport with planning up till 2032, which is integrated with Integrated Multimodal Transport Plan (NCRPB, 2005). The plan covers the freight traffic movement of Rail, Road and Air. Since the road freight movement has major role in Delhi-NCR and rail freight having its own dedicated corridor, author has researched for the road freight movement on ground level, meeting freight vehicle drivers, knowing their real problems on and off the roads along with the problems faced by road users due to mixed passenger and freight vehicles on arterial roads of the city.

Out of 128 toll points, there are 23 major points from where these trucks enter. Of these, the five major points for trucks are $\mathrm{NH}$ 24, DND/Kalindi Kunj, Badarpur border, NH-8 and GT Karnal Road. Due to loopholes in the enforcement implementations, movement of freight vehicles within the city is resulting in unsafe and inconvenient movement for road users. MoRTH report (2016) reveals that there were 4, 80,652 road accidents during 2016, claiming 1, 50,785 precious lives and leaving 4, 94,624 persons injured. Accident severity measured in 2016 showed persons killed per 100 accidents have reached from $31.4 \%$ to $46.3 \%$ in the age bracket of 18-35years. Further, MoRTH revealed that out of all major cities of India, Chennai reported highest number of road accident deaths (1591) followed by Delhi (1183).

To understand the situation an overall field assessment especially on arterial roads on and off-peak hours was conducted. To identify the real and right perspective, a detailed ground study was conducted to identify the key parameters. Although it is very tedious to find out the real cause of freight vehicle mismanagement only after a single research study, but after identifying the key parameters, an initiative can be taken to improve the situation. In India, road users are facing lot of inconveniences due to mixed traffic of passenger and freight movement. Considering the complications and complexity of the situation, Planning Commission, Government of India vide Order No. 18/3/2011-Tpt dated 6.4.2011 constituted a Working Group on Road Transport for the Formulation of Twelfth Five Year Plan (2012-2017) with a Sub-Group on 'Passenger and Freight Traffic Assessment and Adequacy of Fleet and Data Collection and Use of IT in Transport Sector' in Road (MoRTH, 2011). Some of the major concerns are being summarized as under.

Delhi - NCR losses 42 crores of man-hour every month due to bad commuting facilities because of jams and poor maintenance of roads and vehicles. Trucks playing major role in the situation. Poor implementation of policies regarding vehicle registration, licensing, toll points, and check posts are biggest weakness. Freight vehicles not following pollution norms; have resulted in making the region most polluted in whole world. There is no Freight Logistic System, which gives the details of origin and destination of goods vehicles Resources are far from product/consumption thus requires long distance transportation. DelhiNCR faces large share of rural population, distribution of local goods is expensive to serve in scattered population. There is no Intelligent Transport System at entry and exit points, making management of freight traffic difficult, since there is no communication between carriers and regulatory agencies. 
Planned projects running behind, some have not even started. The average truck is operational for about 20 years, after which it is scrapped. A truck that is less than six years old can typically cover about 8,000 $\mathrm{km}$ per month, while a vehicle that is more than 10 years old can only cover only about $2,000-4,000 \mathrm{~km}$ per month still around $40 \%$ of trucks are more than 6 years old, have already covered the distance and still operating (Accident Research Cell, Delhi). Overloading of trucks and all goods vehicle is one of the greatest problem in many ways such as - Emission levels doubles in case of overloading, Tendency to over-fuel the engine results in higher black smoke emission which is major cause of many health problems , Engine has to work harder to produce the power needed, and Engine usually operates in a worse state of repair than a vehicle that is not routinely overloaded. Freight rates depend on the type of commodity being carried, weight of the commodity, source and destination of the journey, time of the year and demand and supply of trucks. Freight rates are seasonal in nature. The trucks usually go overloaded in one direction and return with an empty haul. Hence, freight rates also depend on the possibility of a quick turnaround with a return load from the point destination. The trucking industry in India is almost entirely in the private domain and is dominated by small road transport operators. The freight charges are usually decided by cargo operators who tend to decide on the freight rates. This process is not regulated by the government. Although, all points mentioned above are very important for freight movement, but an attempt is made to focus more on safety of road users after assessing the situation.

\section{Past Studies}

A brief SWOT analysis regarding the freight vehicular movement in Delhi-NCR is being mentioned in Table 1. For comparison of Delhi freight vehicular movement with other countries, an outlook on latest methodologies is being studied (NCRTC, 2010; NTDPC, 2014). Internationally, lot of work and attempts has been made throughout the world to control and manage the freight vehicular movement. A brief explanation regarding the same has been discussed in context to have some implementable solutions for Delhi. In USA, whole transport system is being handled by Transportation Service Index (TSI). The main aim of TSI is to manage the movement of freight and passenger vehicles. TSI continuously collects data on freight as well as passenger travels and finally gives Freight Index, passenger Index and both. The process includes continuous Data Collection, Forecasting, De-seasonalizing, Indexing, Weighting and Chaining. As a result, even with increased demand of freight with passing years, government takes strategic decisions to have sound and technical guidance through detailed researches based on data collected from field (NCHRP Report, 2007).

\section{In Europe, Urban Freight Transport (UFT)} management in Europe is well organized. The main emphasis is on to maximize the economic resources while minimizing the social and environmental impacts after performing detailed surveys and research work (RFTV, 2010). To achieve the goal, UFT has categorized the urban areas as mentioned in Fig. 1. 
Urban

\section{Major Categories}

- Construction

- Waste

- Retail

- Courier \& Post

- Hotels
$\Rightarrow$ Freight Transport

Fig. 1.

Major Categories for UFT in Europe

In China, road freight comprise of mainly trucks, resulting in the highest levels of emissions. After detailed and systematic approach towards movement of freight vehicles, the primary safety problems identified in the literature that relate specifically to trucks or goods vehicle in China include: overloading, driver errors, including speeding and following too close, driver fatigue and distraction, poor mechanical condition of trucks, particularly brakes, roadway design that fails to accommodate trucks (Mehndiratta et al., 2011; Cole et al., 2008).

\section{Table 1}

SWOT Analysis for Delhi-NCR

\begin{tabular}{|c|c|c|c|c|}
\hline S.no & Strengths & Weaknesses & Opportunities & Threats \\
\hline 1 & $\begin{array}{l}\text { NCRPB has allocated } \\
\text { funds for infrastructure }\end{array}$ & $\begin{array}{c}\text { Mismanaged \& } \\
\text { Unplanned Movement of } \\
\text { Freight }\end{array}$ & Lot of scope for ITS & Pollution \& Congestion \\
\hline 2 & $\begin{array}{c}\text { Integrated Freight } \\
\text { Complexes \& Highway } \\
\text { Facility Centres to be } \\
\text { provided on NH's and } \\
\text { SH's }\end{array}$ & $\begin{array}{l}\text { Poor implementation of } \\
\text { policies }\end{array}$ & $\begin{array}{l}\text { Alternate fuels for freight } \\
\text { vehicles }\end{array}$ & Human Health hazards \\
\hline 3 & $\begin{array}{l}\text { DPCC \& CPCB will use } \\
\text { ITS at Checkposts }\end{array}$ & $\begin{array}{l}\text { No freight logistics } \\
\text { system }\end{array}$ & $\begin{array}{c}\text { Promoting Marginal } \\
\text { materials for road } \\
\text { Construction }\end{array}$ & Overloading \\
\hline 4 & $\begin{array}{l}\text { Movement of freight } \\
\text { at outer cordon is now } \\
\text { distributed \& planned }\end{array}$ & $\begin{array}{l}\text { Even Supreme court } \\
\text { orders not being } \\
\text { implemented properly }\end{array}$ & $\begin{array}{l}19 \text { ministries have come } \\
\text { together for providing } \\
\text { opportunities in sectors } \\
\text { such as policy making, } \\
\text { timely completion of } \\
\text { projects, installing ITS } \\
\text { at various junctions, } \\
\text { Pollutant monitoring } \\
\text { at entry / exit points } \\
\text { equipped toll plazas etc. }\end{array}$ & Increase in accidents \\
\hline 5 & $\begin{array}{l}\text { Special Economic Zones } \\
\text { to be built }\end{array}$ & $\begin{array}{l}\text { Overloading of freight } \\
\text { vehicles }\end{array}$ & $\begin{array}{l}\text { Phasing out and ban of } \\
\text { old goods vehicle will } \\
\text { give opportunities to new } \\
\text { companies }\end{array}$ & Road Rage \\
\hline 6 & $\begin{array}{l}\text { Growth of goods vehicles } \\
\text { depicts the increase in } \\
\text { trade and business for } \\
\text { Delhi-NCR region }\end{array}$ & $\begin{array}{l}\text { No priority for Driver's } \\
\text { Behaviour and Vehicle } \\
\text { Maintenance }\end{array}$ & $\begin{array}{l}\text { Inclusion of SEZ's in } \\
\text { the region will provide } \\
\text { opportunities for new and } \\
\text { big companies to invest }\end{array}$ & $\begin{array}{l}\text { Manufacturing of low } \\
\text { standard commercial } \\
\text { vehicles }\end{array}$ \\
\hline
\end{tabular}


China's Ministry of Transport has started mainly working on " 3 lows and 1 high": low concentration, low technology level, low efficiency and high fuel consumption. There is a Smart Road Freight System, based on few sustainable solutions. China constituted "World Metropolitan Transport Development Forum" (WMTD) in 2015. More than 500 participants gathered in Beijing to discuss challenges and solutions for sustainable transport development. WRI China, Beijing Municipal Commission of Transport (BMCT) and Beijing Transport Institute (BTI) further co-organized the forum, to encourage city leaders and transport professionals to address challenges in urban freight mobility. WRI's China team summarized the potential sustainable solutions, which are as follows: multimodal freight transport and trans shipment methods, internet plus logistics, drop-andhook (tractor-trailer) approaches, newenergy trucks and clean technologies and low-emission zones and standards.

\section{Study Methodology and Data Collection}

\subsection{Methodology}

Assessment of freight movement and accident prediction for Delhi NCR following methodology has been adopted (Fig. 2).

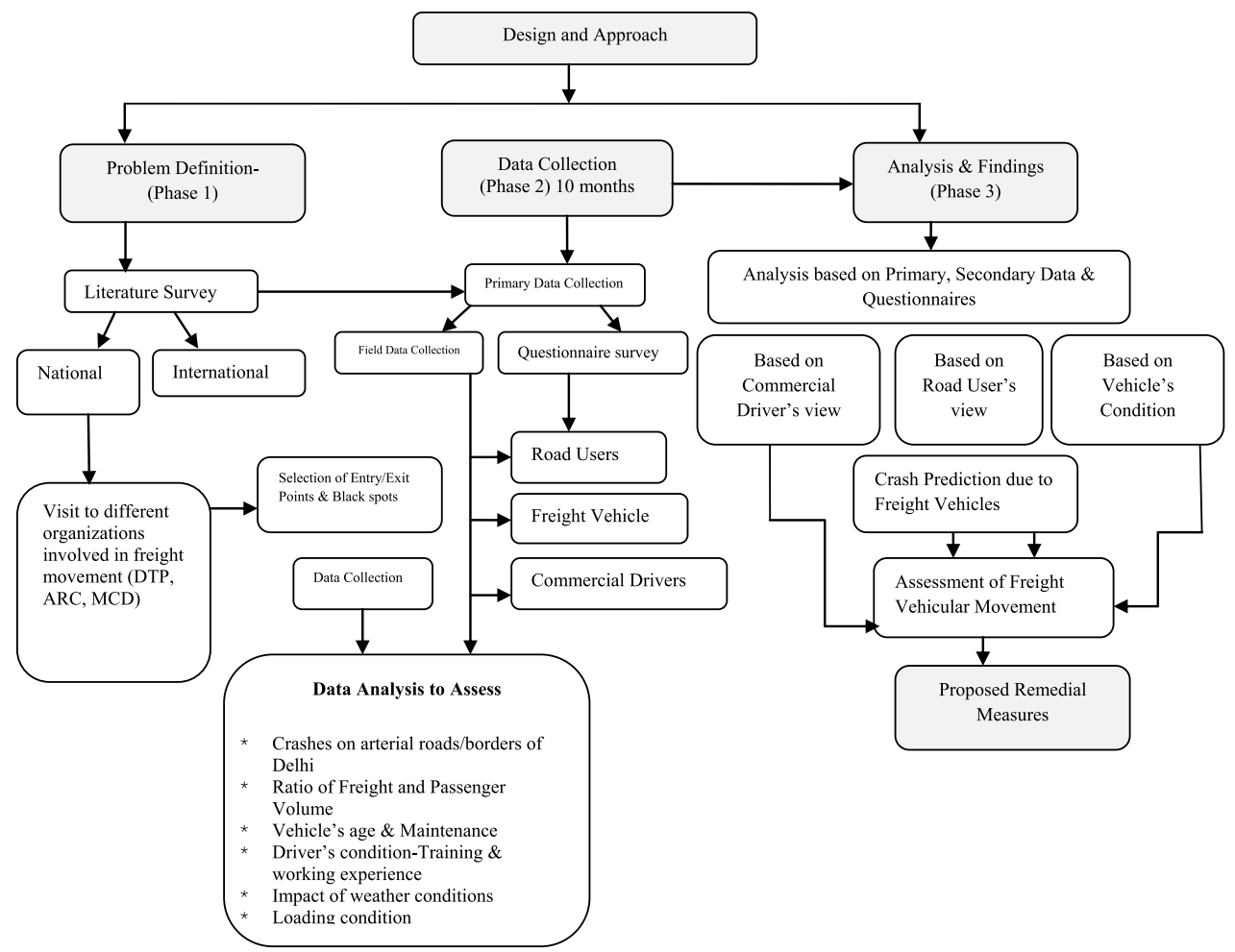

Fig. 2.

Flow Chart of Study Methodology 


\subsection{Data Collection}

To select the study area was quite complex, as the freight movement mismanagement is all over Delhi-NCR. Secondary data was collected from, Delhi Traffic Police (DTP), Accident Research Cell (ARC) and MoRTH. From the data, top 25 roads for accidents from freight vehicles were selected within Delhi and border with maximum freight volume. Site visits were made and at every location, parameters sensitive to the particular locations were considered. Data for freight and passenger volume vehicle was taken during peak and off-peak hours to see the ratio of freight vehicle and passenger vehicle. Later, 50 accidents caused by freight mainly in Delhi-NCR region were downloaded from YouTube to have in-depth knowledge of behaviour of freight vehicles movement and to know the loopholes of the situation. Finally, out of these 25 roads and 128 toll points, seven arterial roads (Azadpur, Ashram Chowk, Nehru Nagar, Peeragarhi, Tughlaqabad, Wazirabad and Zakhira ) and five border roads were selected, as shown in Fig. 3.

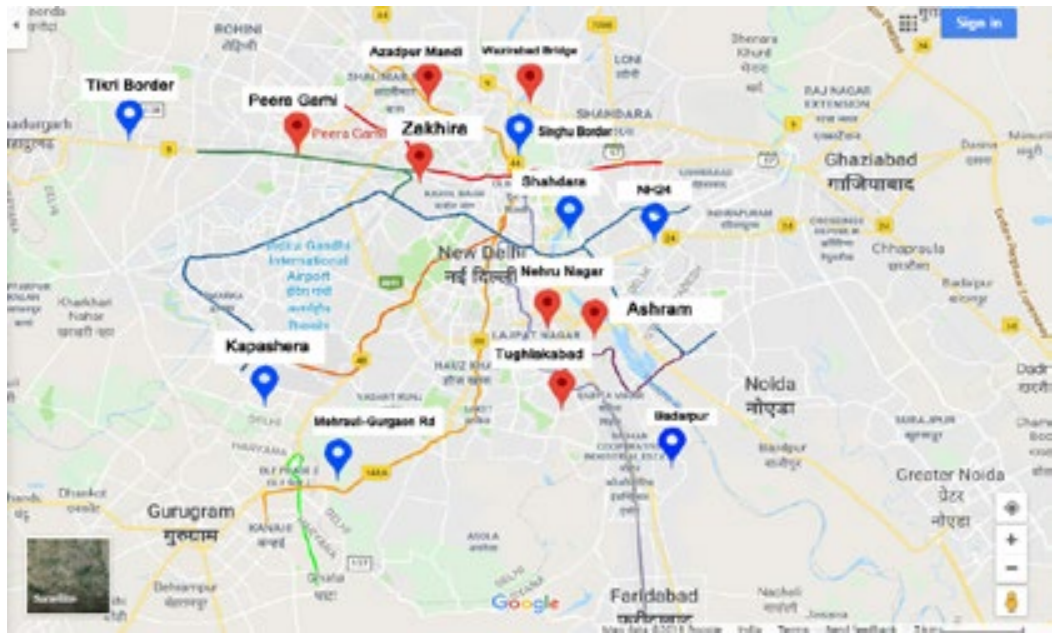

Fig. 3.

Selected Study Areas for Freight Movement Study in Delhi NCR

Border sites: out of 128 toll points, we have selected only 7 points, mentioned in Fig. 4. Sites were selected mainly considering MCD Toll volume data, mentioned for few large volume freight data sites given Fig. 4. 


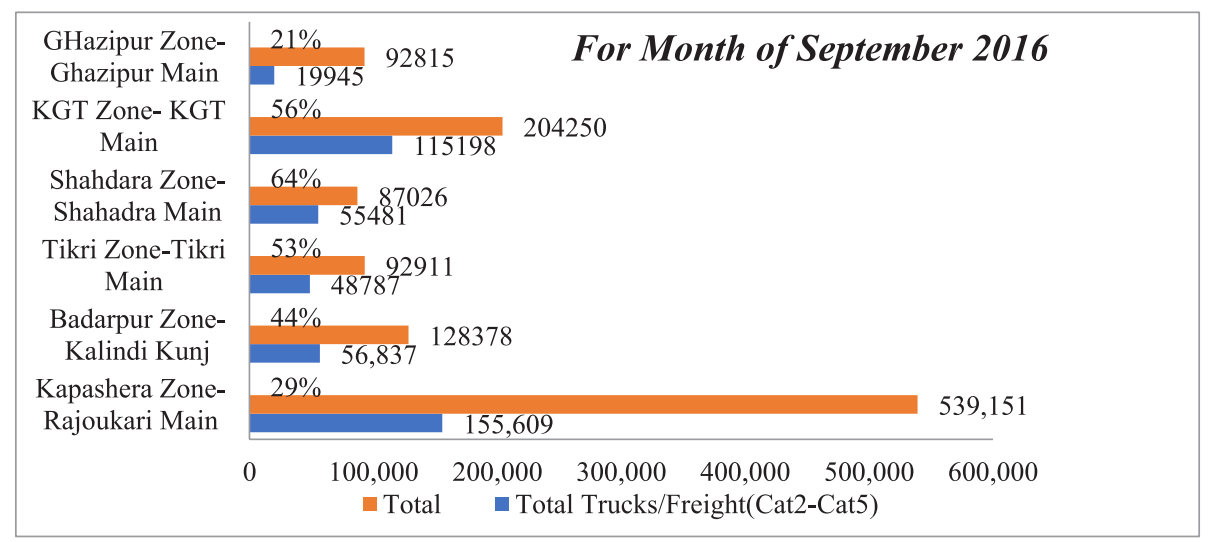

Fig. 4.

Comparison of Total Vehicles and Trucks on Borders Sites

Secondary data was collected from ARC, DTP and MCD along with the primary data of freight and passenger vehicle volume count for selected sites. Secondary data comprises of accident data on these locations caused by freight and HTV's using FIR's while Questionnaires were prepared for Driver, Vehicle, Road Users and Safety. 1400 samples of questionnaire from these particular locations were collected, which gave a view about driver's perspective, their vehicle condition, and road users' point of view about safety. Later 50 actual accidents involving freight for Delhi - NCR for the year 2016-17 were downloaded to have knowledge about the problem areas and nature of accidents and key parameters to be considered later while improvising policies regarding freight vehicular movement. Comparison of Freight and Passenger Volume for Arterial Roads are mentioned below.
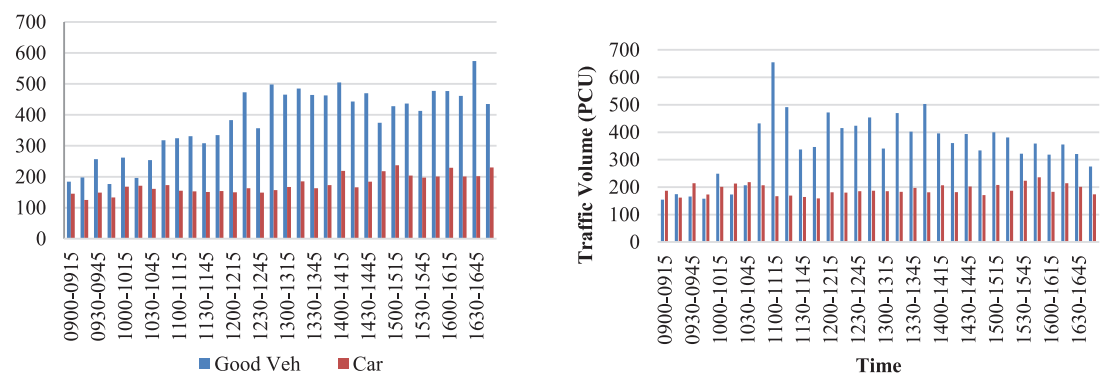

Fig. 5.

Freight Volume at Azadpur - GT Road Towards U/P and Towards GT Road 

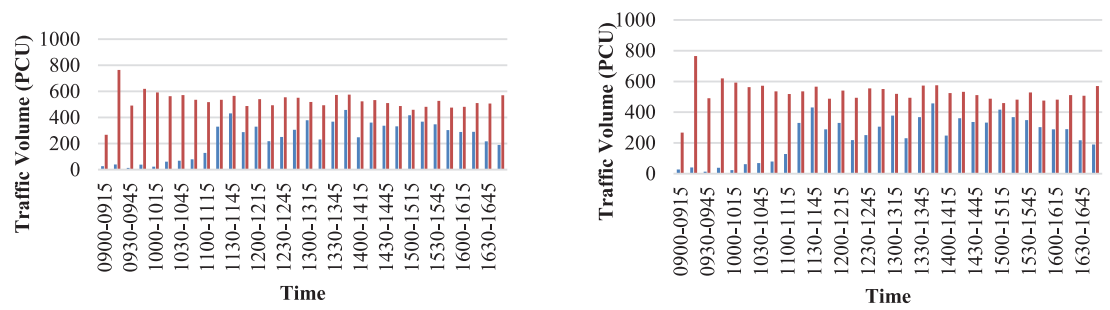

Fig. 6.

Freight Volume at Badarpur to Ashram \& Ashram to Badarpur
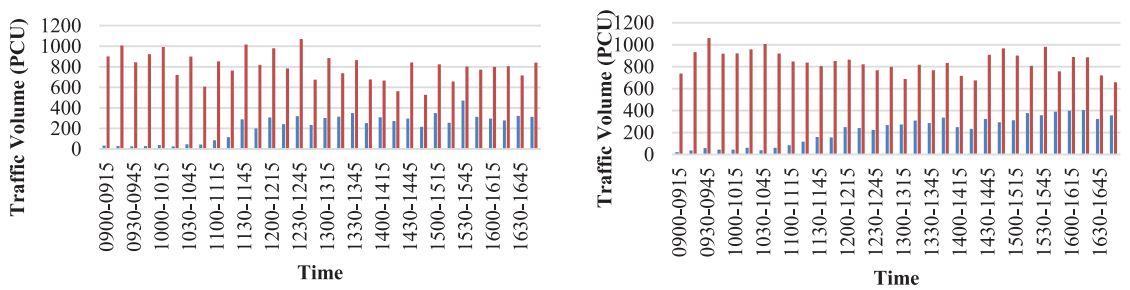

Fig. 7.

Freight Volume at Nehru Nagar - DND to Lajpat Nagar \& Lajpat Nagar to DND
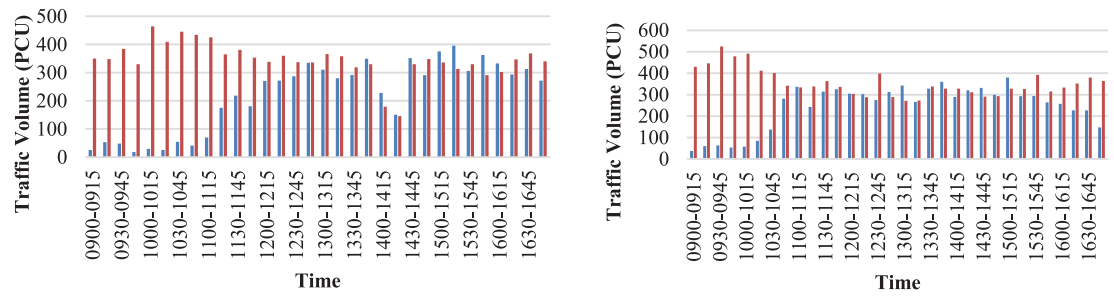

Fig. 8.

Freight Volume at Peeragharhi to Nangloi \& Nangloi to Peeragarhi
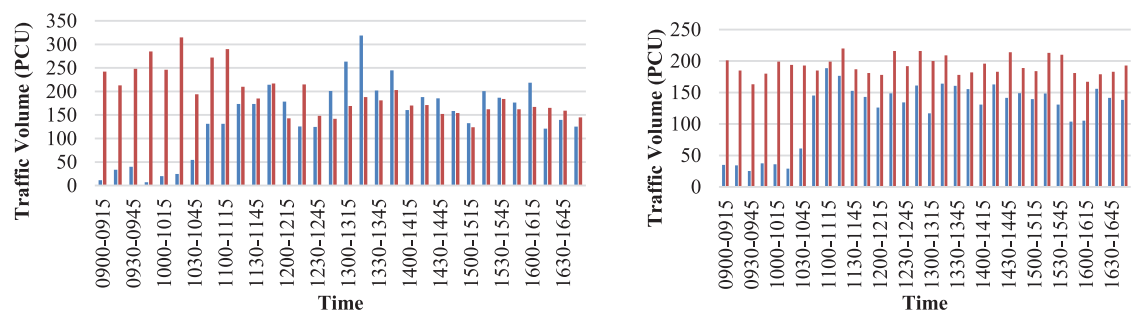

Fig. 9.

Freight Volume at Mehrauli to Badarpur \& Badarpur to Mehrauli 

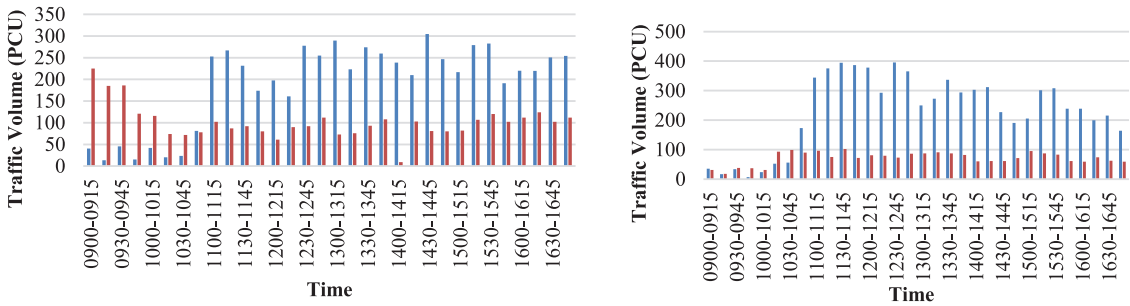

Fig. 10.

Freight Volume Nau Ghaza Baba Dargah to Wazirabad Marg \& Wazirabad Marg to Nau Ghaza Baba Dargah

Borders sites: the entry of trucks in Delhi has always been a serious concern. In 2015 , entry of trucks was allowed from $9 \mathrm{pm}$ onwards, later, it was noticed that in a lively city like Delhi, the presence of trucks moving from one border to other was creating lot of inconvenience to common road user, thus it was decided in 2016, the timing restriction will change from $9 \mathrm{pm}$ to $11 \mathrm{pm}$. At present, no truck can enter Delhi before $11 \mathrm{pm}$ officially. Volume of road passengers is quite high at borders, as people commute for their jobs in and around Delhi.

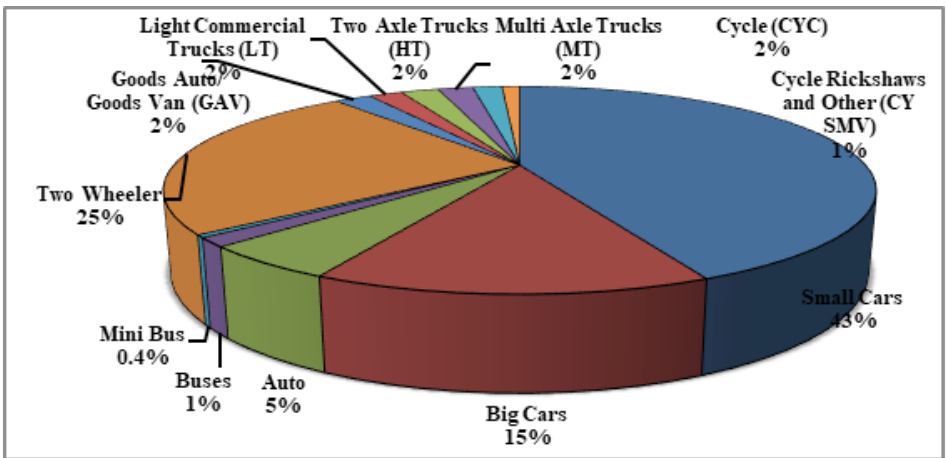

Fig. 11.

Model Share at Border of Delhi-NCR

\section{Data Analysis}

At most of the borders around Delhi, commercial vehicles enters at $11 \mathrm{pm}$. Toll collection at the borders is not of latest technology, mostly it is manually done as a result, there is lot of congestion. Delhi Municipal Corporation is the nodal agency for this -levy entry toll on commercial vehicles at the border. Since February 2016, this work has been entrusted to a private Delhi based concessionaire. The MCD toll collectors occupy three of the four lanes, leaving just one for the use of vehicles that are not required to pay entry and green taxes. Some of the site-specific points being analysed for the safety of road users are as follows: 
- At Badarpur border, while coming from Faridabad towards Delhi, it was noticed a metro pillar no. 475 is placed right in between the middle of road, because of which the traffic has to deviate. In night this is not at all safe, as any traffic coming can hit and can have accident. Immediate action should be taken for reflective marker on pillar and on corridor;

- At every border point, there is no provision of truck to be parked, as a result they park on roadside blocking almost two lanes on borders. Except at Singhu border, APMC has constructed a resting place, which is very well managed with toilet facilities, resting place and hotel facilities for food;

- At Ghazipur border, NH-24, every road user gets in traffic snarl that gets increasingly unsafe and more congested as we approach towards toll booths. People with tough looks waving PVC pipes and thick sticks are running along trucks to collect tax;

- Trucks are free to move in any lane violating the orders of Supreme court on using commercial vehicle in only the leftmost lane. As per traffic police it is very difficult to control truck drivers. Admittedly, CCTVs installed are mislead by tax agents who move to the slip roads or the extreme right lane out of sight of the cameras to transact deals;

- Entry into Delhi is not permitted before $11 \mathrm{pm}$, but most trucks reach the area much earlier, commercial vehicles start gathering around $9 \mathrm{pm}$, and park haphazardly on the roads leading up the toll booths this leads to a massive traffic jam causing lot of inconvenience to road users. On the contrary making $68 \%$ road users unsafe (25\% Two-wheelers and $43 \%$ car users);

- ITS facility at borders is minimal. This needs to be addressed on urgent basis;

- $\quad$ Refelective Road marking throughout the corridor specially approaching border is another aspect to be addressed on urgent basis.

Freight Driver's Behaviour/Passenger Vehicles/Safety: On the basis of 1400 samples of questionnaire surveys related to freight drivers, Passenger vehicle and Safety, most important aspects have been extracted and discussed in this section. Around $81.3 \%$ of drivers are in the age limit between 30-50years, young driver's i.e. age between $20-30$ years is $15.7 \%$. On an average $53 \%$ commercial driver on road are having experience of 6 to 15 years. Maximum education attained by Indian commercial driver is, metric, which is $59 \%$, while $39 \%$ are $5^{\text {th }}$ class pass. The monthly salary between Rs10, 000 - Rs 20, 0000 is $73 \%$ while it is only $8 \%$ between Rs 20, $000-30,000$. Around $94 \%$ commercial drivers are in favour of separate dedicated corridor for freight preferably on extreme left lane all over India. When a call comes $67 \%$ drivers accepted that they stop the truck and attend, while $16 \%$ say they attend while driving. Around $81 \%$ drivers accepted that they are aware of MVA, but they were not aware of its indepth importance. Multiple checks on make 93\% drivers uncomfortable. Commercial drivers are $100 \%$ convinced to have resting zones/places with all toilet, fuel and food facilities. As per survey, $70.5 \%$ of trucks are being owned by private companies, $22.4 \%$ are personal and only $2-3 \%$ by government. 
Fuel used in our freight vehicles is $65 \%$ diesel and 35.3\% CNG. Regarding service of trucks, $55 \%$ rivers say that it is twice per/month, $32 \%$ say once per month and almost $14 \%$ say thrice per month. Around $49 \%$ drivers say the condition of truck is good, $49 \%$ says average and only $2 \%$ accepts it is poor. Around 55\% drivers accepted that their vehicle is overloaded twice a week, $40 \%$ says it is not overloaded, other than survey simultaneously it was asked, drivers accepted that trucks are overloaded because of owners wishes. Around 57\% drivers told that they get parking space easily, but on road side while $43,2 \%$ says they get difficulty to park trucks. Around $67 \%$ drivers are not satisfied with lighting system on highways. Around $68.4 \%$ not satisfied with road markings. $87 \%$ drivers accepted that they encounter fatigue while driving. Only $57 \%$ drivers are insured by companies. On an average $90 \%$ commercial drivers are under influence of alcohol. Major cause to consume alcohol is $43 \%$ - fatigue, $25 \%$ - habit and $22 \%$ to maintain efficiency (in their opinion). Around 54\% drivers gets 10 challans per year while $43.2 \%$ gets more than 10 challans per year. Around 22\% drivers encounter empty trips. Drivers accepted that $88 \%$ delays are because of traffic jams. As per drivers major cause of accidents is poor road condition, while only $19 \%$ accepted it is because of negligence of drivers which can be of passenger vehicle too. Around 34.7\% road users suffer from asthma, 38.8\% from burning eyes and $26.75 \%$ from BP. $80 \%$ of people feel unsafe under influence of trucks/ freight vehicles moving along. Around 60\% road users accept that they are exposed to traffic jams including freight for their travel time. $90 \%$ road users accept that Delhi needs better transport planning. $82 \%$ road users are in favour of separate/dedicated lane for trucks.
Crash Prediction using SMEED's Model: The data is being analysed for crash prediction also using SMEED's Model and Multi Regression Model. Based on volume and questionnaire data analysis, the remedial measures for sites are being given in subsequent section. Crash data can be measured in terms of severity (Fatal, Injured \& Total crash). Crash Prediction Model has been developed in this study using Smeed's prediction model to analyze crash scenario in Delhi due to freight traffic considering the relationship of number of road fatalities and total number of crashes with the registered freight vehicles and the population. Crash severity has been measured in terms of severity index, which represent the fatality rate. Crash data due to freight vehicular movement have been collected from 2010 to 2016. Yearly trend of total crash and fatal due to freight have been shown in Fig 12. Crash severity Index has been estimated and values are shown in Table 3. As per 2016 data crash severity is $34 \%$ which is considered as high, in Delhi. Therefore, it is required to provide safety measures to decrease the severity tend to zero percent. Frequency table of crash data has been used to observe the distribution of data. Easy-Fit software has been used to test goodness of fit (Kolmogorov Smirnov test value) and distribution summery has been provided in Table 4. As per the goodness of fit test, negative binomial distribution is best fitted to the collected yearly crash data considering $10 \%$ significance level.

\section{Hypothesis test:}

- $\quad$ Null hypothesis (Ho): The number of accidents follows a Poisson distribution or Negative binomial;

- Alternative hypothesis (H1): The number of accidents does not follow a Poisson distribution Negative binomial. 
Table 3

Crash Severity due to Freight Movement in Delhi

\begin{tabular}{|c|c|c|c|}
\hline Year & Fatal (F) & Total Crash $(\mathbf{C})$ & Crash Severity Index \\
\hline 2010 & 290 & 388 & 0.43 \\
\hline 2011 & 272 & 340 & 0.44 \\
\hline 2012 & 244 & 392 & 0.67 \\
\hline 2013 & 268 & 445 & 0.38 \\
\hline 2014 & 218 & 461 & 0.32 \\
\hline 2015 & 232 & 401 & 0.37 \\
\hline 2016 & 171 & 339 & 0.34 \\
\hline
\end{tabular}

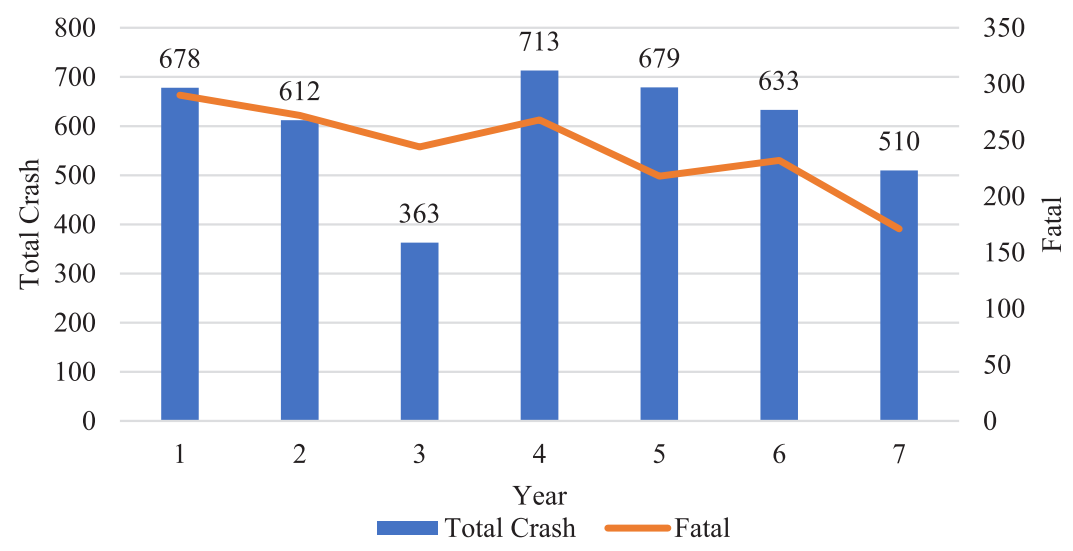

Fig. 12.

Yearly Trend of Crashes in Delhi due to Freight

Table 4

Goodness of Fit-Summery

\begin{tabular}{|c|c|c|c|}
\hline Distribution & P value & Statistics (K-S) & Rank \\
\hline Negative binomial & 0.046 & 0.288 & 1 \\
\hline Poisson & 0.070 & 0.495 & 2 \\
\hline
\end{tabular}



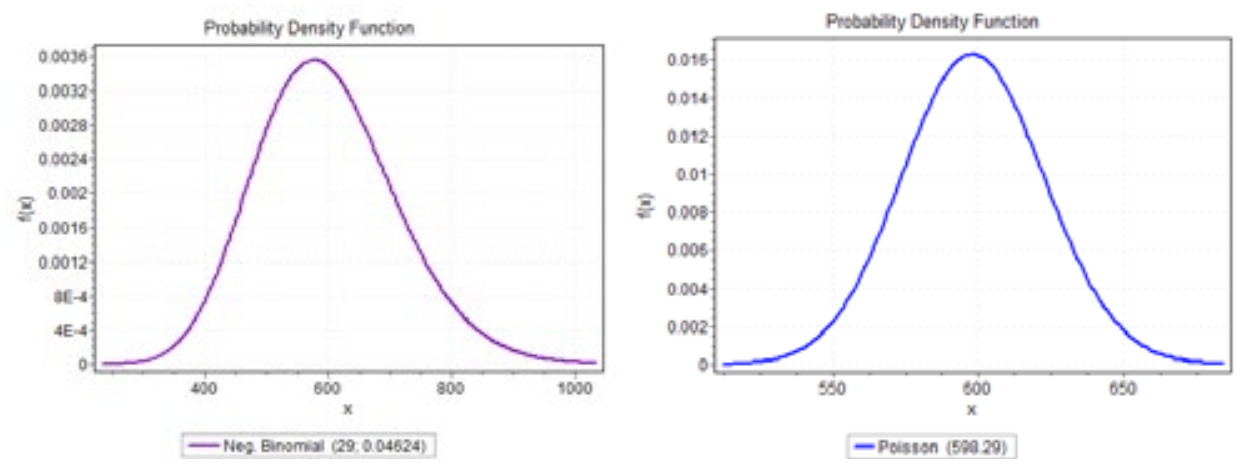

Fig. 13.

Probability Density Function for Negative Binomial \& Poisson

Further, developed equations are given below and data for model development are provided in Table 5. Trend line of developed models can be observed in Fig. 14 and 15 . Coefficient of determination $\left(\mathrm{R}^{2}\right)$ value is considered to check model accuracy and it can be observed that the estimated value of $\mathrm{R}^{2}$ is 0.65 . It shows that Smeed model is fitted to this condition and the developed model can be used for future prediction. Also, the actual value of $\log (\mathrm{F} / \mathrm{V})$ and Smeed's predicted values are projected to see the accuracy of observed and predicted data $\left(\mathrm{R}^{2}=0.98\right.$, Fig. 16.):

$\log (F / V)=-5.24-1.19 \log (V / P)$

$\log (\mathrm{C} / \mathrm{V})=-5.71-1.63 \log (\mathrm{V} / \mathrm{P})$

Table 5

Crash Prediction using Smeed's Model

\begin{tabular}{|c|c|c|c|c|c|}
\hline Year & $\begin{array}{c}\text { No. of Registered Vehicle } \\
\mathbf{V}\end{array}$ & $\begin{array}{c}\text { Population } \\
\mathbf{P}\end{array}$ & $\mathbf{L o g}(\mathbf{F} / \mathbf{V})$ & $\begin{array}{c}\text { Actual Log } \\
(\mathbf{V} / \mathbf{P})\end{array}$ & $\begin{array}{c}\text { Smeed's } \\
\text { Prediction } \\
\text { Log (F/V) }\end{array}$ \\
\hline 2010 & 193205 & 16314838 & -2.8236 & -1.9266 & -1.8798 \\
\hline 2011 & 209370 & 16753235 & -2.8863 & -1.9032 & -1.8052 \\
\hline 2012 & 228886 & 17115104 & -2.9722 & -1.8738 & -1.7030 \\
\hline 2013 & 140942 & 17484790 & -2.7209 & -2.0936 & -2.0021 \\
\hline 2014 & 154654 & 17862461 & -2.8509 & -2.0626 & -1.8474 \\
\hline 2015 & 161821 & 18248290 & -2.8435 & -2.0522 & -1.856 \\
\hline 2016 & 281159 & 18686902 & -3.2160 & -1.8226 & -1.4130 \\
\hline
\end{tabular}


$\log$

$(\mathrm{F} / \mathrm{V})$

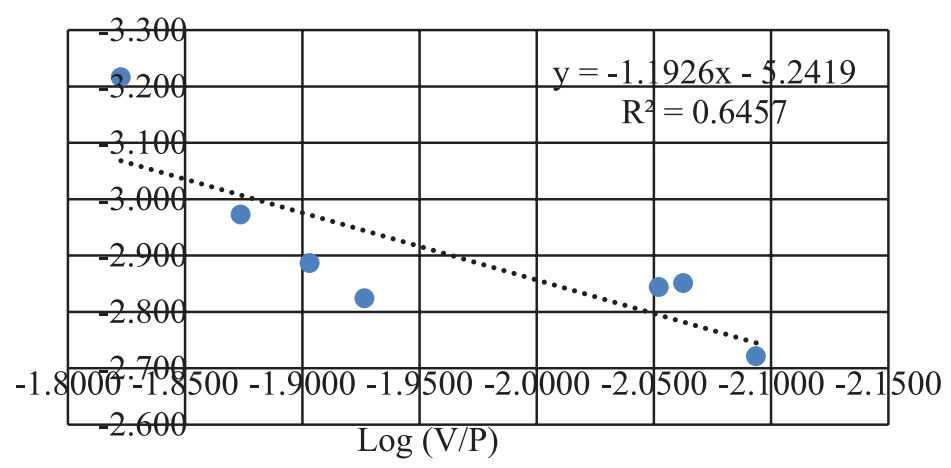

Fig. 14.

Graphical Representation of Smeed's Model for Fatalities due to Freight

$\log$

$(\mathrm{C} / \mathrm{V})$

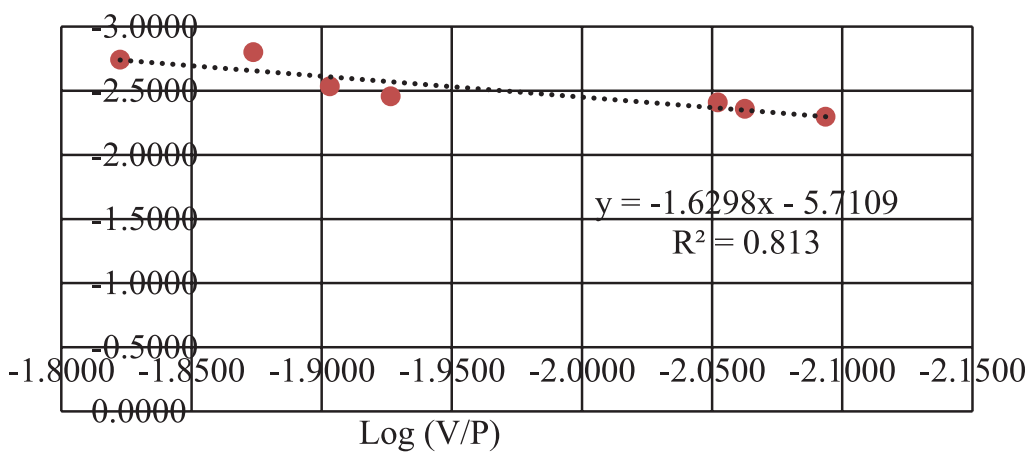

Fig. 15.

Graphical Representation for Smeed's Model for Total Crash

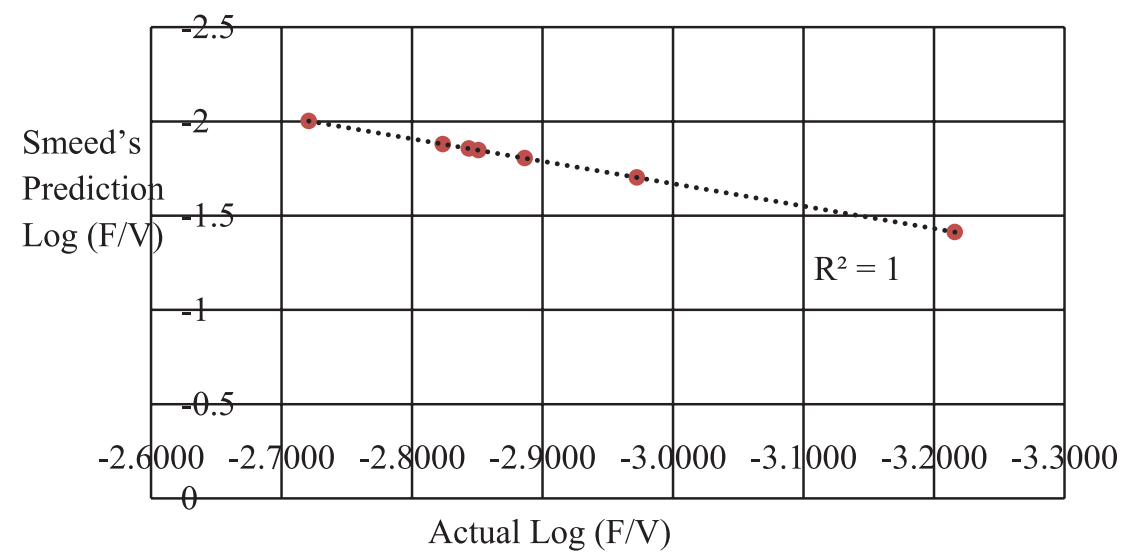

Fig. 16.

Accuracy Depiction for Smeed's Predicted Values and Observed Values 
Multi regression model has been developed for predicting crash data on Delhi arterials using two dependent variables for instance Freight traffic volume (PCU) and carriageway width and fatal data (2017) as an independent variable. Pearson correlation coefficient has been evaluated to measure the strength of relationship between independent variables and the observed value coming out to be 0.08 . Result shows that there is very weak relationship as per Evan's (1996) suggested values. Developed crash prediction model summary has been provided below in Table 6. Model validation has been measured in terms of adjusted $\mathrm{R}^{2}$ and the observed value is 0.47 which implies approx. $50 \%$ variation of dependent variable can be explained by independent variables. $10 \%$ level of significance has been considered for $F$ test to measure the acceptance or rejection of model. Observed $\mathrm{p}$ value is 0.08 which indicates the acceptance of the model.

\section{Study Outcomes}

With an insight of the situation at ground level, few very important general remedies to improve the situation which are implementable as per Indian conditions are as follows:

1. First and foremost, aspect to control freight movement is to address genuine problems faced by the backbone of these machines i.e commercial drivers by adopting them under some ministry;

2. In USA, the main aim of TSI is to continuously collect data on freight and passenger travels, which gives Freight Index and Passenger Index year wise. This helps in forecasting the situation. Same can be implemented for Delhi-NCR;

3. Notification and collection of data regarding accidents due to freight is not proper in India. Because of less data available, modelling for crash causation becomes difficult. Few FIRs were collected from police stations, and ARC (Accident Research Center) helped in collecting crash details mainly due to freight vehicles. In most of the cases in FIR, main reason of crash was not evident. Thus, the procedure to collect crash data should be clear and easy;

4. In USA, there is National Cooperative Freight Research Program (NCFRP), which is a committee comprising of government officials, stakeholders and researchers. Similarly, In India we can have such kind of NCFRP, which will help to regulate freight movement on PAN India basis;

5. As in Europe, concept of UFT (Urban Freight Transport), the concept can be adopted in India, which will not only help freight movement but also will decrease pollution levels. In this concept urban area is being divided in different zones and is treated as per Market Based Measures, Land-Use Planning Measures, Infrastructure measures and Management and other measures. Similarly, in Delhi, as it is already divided zone wise taking any one or measure, freight movement can be regulated;

6. In China, the primary safety approach towards freight movements identified are: Overloading, Driver errors, Driver fatigue and distraction, Poor mechanical condition of trucks, particularly brakes and Roadway design that fails to accommodate trucks. In our study area we have covered all the aspects, using results, new policies can be made and adopted. Although, new rules for loading conditions have already being considered by MoRTH, where 
government has raised around $20-25 \%$ loading condition as per Gazette of India No2696 dated $16^{\text {th }}$ July 2018. Where $16 \mathrm{~T}$ load is being increased to $19 \mathrm{~T}, 25 \mathrm{~T}$ to 28.5T and $37 \mathrm{~T}$ to $42 \mathrm{~T}$;

7. In India, there is no concept and way to weigh the loaded truck. Truck scales can be used to check weighing both axle weights and gross vehicle weights. This will help to stop axle overloading and possible heavy fines;

8. New energy trucks and new technologies should be adopted with immediate effect;

9. Our survey shows that $92 \%$ commercial drivers are in favour of ITS services, thus installation of ITS on every toll point and corridors is a must;

10. Highway toll determination schemes should be installed on all toll points in Delhi and later on PAN India basis.

\section{Conclusions}

Although, situation is quite chaotic, but small changes can be the starting step for better freight vehicular movement in Delhi for safety of road users. Since data is being collected related to few sensitive key parameters regarding commercial drivers, road users and safety aspects, thus, we can use the findings to implement new policies which will have positive impact on safety of road users. Further, site specific discussion may also ease out the freight vehicular movement which will further regulate the road user movement at least on these seven sites. Since commercial drivers were personally interviewed, it was found out that a life of commercial drivers is very tough. If some small problems of commercial drivers are being rectified, it can have great impact on their lives making them more discipline and efficient. Project was completed with the combined effort of Ministry of Roads Transport and Highways (MoRTH), Municipal Corporation of Delhi (MCD) and Delhi Traffic Police (DTP) departments, thus we need to have strong bond between such organizations to avoid gaps in the system. Timing of entry/exit of trucks have to be analysed closely, fixed and implemented. Overloading is one of the major concerns, because commercial drivers are helpless as they have to follow their owner's orders. India badly needs a revolution in freight logistics system by introducing new policies and technologies to fill gaps in the system.

\section{Acknowledgement}

We are thankful to CSIR-Central Road Research Institute, Director CRRI and our colleagues and seniors who provided expertise that greatly assisted the research.

\section{References}

Cole, D.; Furst, T.; Daboin, S.; Hoemann, W.; Meyer, M.; Nordahl, R., Parker, M.; Penne, L.; Stoner N. \& Tang, T. 2008. Freight mobility and intermodal connectivity in China (No. FHWA-PL-08-020). United States. Federal Highway Administration. National Cooperative Highway Research Program. Available from internet: <https://rosap.ntl.bts.gov/view/dot/16518>.

Evans, J.D. 1996. Straightforward Statistics for the Behavioral Sciences. Thomson Brooks/Cole Publishing Co. USA.

IFTMAF. 2015. India Freight Transport Market Analysis and Forecasts Report -2015-2020 from Research and Markets. Available from internet: <https://www.slideshare.net/MarketResearchReports/ freight-transport-market-in-india-2015-2020?from action $=$ save $>$. 
Mehndiratta, S.; Fang, K.; Darido, G. 2011. World Bank Case Studies on Green Trucks/Freight Initiatives in China. World Bank. 36 p. Available from internet: $<$ https://sustainabledevelopment.un.org/content/dsd/ csd/csd_pdfs/csd-19/learningcentre/presentations/ May\%209\%20pm/2\%20-\%20Georges\%20Darido\%20 -\%20World\%20Bank\%20Green\%20Freight\%20Cases. pdf $>$.

MoRTH. 2011. Passenger and Freight Assessment and Adequacy of Fleet and Data Collection and Use of IT in Transport Sector in Twelfth Five Year Plan (20122017). Available from internet: <http://morth.nic.in/ showfile.asp?lid=835>.

MoRTH. 2016. Ministry of Road Transport and Highways Report: Road Accidents in India. Available from Internet: <http://www.indiaenvironmentportal. org.in/files/file/Road\%20accidents\%20in\%20India\%20 2016.pdf $>$.

NCRPB. 2005. Report on functional plan on transport for national capital region - 2032.288 p. Available from internet: <http://rgplan.org/ncr/Functional\%20 Plan\%20on\%20Transport\%20for\%20NCR-2032.pdf>.

NTDPC. 2014. India Transport Report, Moving India to 2032. National Transport Development Policy Committee report. Government of India. 89 p. Available from internet: <http://planningcommission.nic.in/ reports/genrep/NTDPC_Vol_01.pdf $>$.
NCHRP. 2007. Guidebook for integrating freight into transportation Planning and projects selection processes. National Cooperative Highway Research Program Report 594, TRB Washington, D.C., USA.

TCI-IIMC. 2017. Operational efficiency of freight transportation by road in India. 3rd Edition, India. 84 p. 2017. Available from internet: <http://cdn.tcil.in/ website/tcil/Study_Report/TCI-IIM\%20Report.pdf $>$.

TDFS-DIMTS. 2010. Transport demand forecast study and development of integrated multi-modal transport network for NCT. Government of National Capital Region - Transport Department, India. Available from internet: <http://delhi.gov.in/wps/wcm/connect/ d8707180436ealacbf5affeaf072cdcf/Final_TDFS DIMTS_RITES+Study.pdf?MOD=AJPERES\&lmo $\mathrm{d}=825067854 \& \mathrm{CACHEID}=\mathrm{d} 8707180436 \mathrm{ea} 1 \mathrm{acbf} 5 \mathrm{a}$ ffeaf072cdcf $>$.

RFTV. 2010. Road Freight Transport Vademecum-2010 Report: Market Trends and Structure of the Road Haulage Sector in the EU in 2010. European Commission, DG for mobility and Transport Unit D.3 - Land Transport. 18 p. Available from internet: <https:// ec.europa.eu/transport/sites/transport/files/modes/ $\mathrm{road} / \mathrm{doc} / 2010$-road-freight-vademecum.pdf $>$.

Smeed, R. J. 1949. Some statistical aspects of road safety research, Journal of the Royal Statistical Society. Series A (General) 112(1): 1-34. 